\title{
Damage Caused by Rodents to Sugar Cane Varieties and Juice Quality in Sohag Governorate
}

\author{
Desoky A.S.S ${ }^{1 *}$, Abazaid A.A ${ }^{2}$, Ali M.M.K ${ }^{3}$ \\ ${ }^{I}$ Plant Protection Department (Agricultural Zoology), Faculty of Agriculture, Sohag University, Egypt \\ ${ }^{2}$ Sugar Crops Research Institute, Agriculture Research Center, Egypt \\ ${ }^{3}$ Post Graduate Student, Plant Protection Department, Faculty of Agriculture, Sohag University
}

*Corresponding Author: Desoky A.S.S, Plant Protection Department (Agricultural Zoology), Faculty of Agriculture, Sohag University, Egypt

\begin{abstract}
The damage caused by rodents to three sugar cane varieties was studied Injury of the Nile grass rat (Arvicanthisniloticus), house mouse,(MusMusculus). and the white bellied rat (Rattusrattusfrugivorus) was noticed at the base and the top of sugar cane stalks. The infestation in the main plants was much higher than that in first ratoon. Sugar cane varieties showed great variation in the rate of infestation by rodent. The G. 2003/47 variety was the least infested ones in both main plants and first ratoonfor all varieties tested, the infestation by rodent was found to cause a decrease in sucrose percent in juice and a decrease in the purity of juice.
\end{abstract}

Keywords: Arvicanthisniloticus, MusMusculus, Rattusrattusfrugivorus, Sugar cane varieties, main plants, first ratoon

\section{INTRODUCTION}

The world annual production from refined sugar is estimated by $85-90$ million tonnes, approximately $60 \%$ is derived from sugar cane (Economist, 1981) with thirteen million hectares of cane harvested annually from approximately one hundred countries (FAO, 1979). Form the serious vertebrate pests attacking sugar cane plantations, rodents come first. In Egypt, rodents problem increased in the last few years. The main reasons for this increase are the intensification and diversion in agricultural system, lands reclamation and construction of new cities in the desert, and the wide use of pesticides for controlling agricultural pests which killed the natural enemies of rodents such as reptiles, and birds. Rats eat about $10 \%$ of their body weight each day and contaminate a great deal of food with their dropping and urine. Besides, they gnaw through almost any object in their path to obtain food and shelter (Dykstra, 1966). The annual loss caused by rodents was estimated by 5 to $8 \%$ in sugar cane yield, and it may reach 20\% in severe infestation (Ibrahim, 1972): In other studies AbdelGawadet al. (1982) found in sugar cane fields highly infested with rodents in El-Minia Governorate, that rat damage reduced the sugar cane yield by $41.3 \%$ and total sucrose by $31.58 \%$.Abazaid (1990) in his study on rodent damage to sugar cane in Upper Egypt found 20 to 40\% reduction in yield and 30\% in final sucrose in the infested stalks of sugar cane. In sugar cane plantations the average percentage of damage stalks was higher at the five meters beside the borders of the field (20.9\%) and decreased gradually towards the field center (Ali, 1991)\& Ali and Farghal (1994) found that the rat damage caused reduction in crop yield and percent of sucrose in sugar beet plantations in Sohag Governorate. Bakri- Eman (2004) in her study on rodents damage to six sugar cane varietiesproved that rodent damage reduced the juice quality of all varieties of Segar Cane in Sohag Governorate. Samson et al. (2013)proved that climbing rat damage Segar cane is often found in blocks beside harborage areas, Damage commonly extends from the edge of the block in for 15 meters. Reduce yields are similar to those caused by ground rats. El Rawy (2017) fond that the weight damage percentage at sugar cane in years of study show that the highest infested areas were Ber El-Nos by $(5.94$ and $5.15 / \mathrm{Kg}$.) at the first and second yea respectively. However the lowest one were recorded in Al-Hasany district followed by Al shekwefy it were recorded [(5.29 and 4.64) and (5.57 and 4.91/Kg.)] at the first and second year respectively, in QeneGovernorate. 


\section{MATERIALS AND MethodS}

This study was carried out to determine the damage caused by rodent in three varieties of sugar cane planted at Shandweel Agricultural Research station, Sohag Governorate. The varieties were: G.T. 549, G.2004-27 and G. 2003-47.The experiment was laid out in a randomized block design with 4 replications for each variety planted in $6 \times 7$ meter plots (1/100 of feddan). At the harvest time four random samples (each one 30 stalks) representing each variety were taken from the main plants or first ratoon. The stalks were carefully examined to determine the percentage of rodent infestation for stalks and internodes. To study the effect of rat infestation on weight from each variety 50 stalks were chosen randomly from infested or non-infested stalks were taken from main plants, and first ratoon the weight of infested and non-infested was recorded. To study the effect of rat infestation on some juice quality, from each variety 50 stalks were chosen randomly from infested or non-infested stalks. The juice of infested and non-infested stalks was analyzed to the method described by Meade and Chen (1977).

\section{RESULTS AND DISCUSSION}

Data in Table (1) represent the rodent infestation in three commercial varieties of sugar cane planted at Shandweel Agriculture Research Station. For main plants, and first ratoon results proved that the variety G 2003-47 was the least sensitive one to rat injury, for stalks and internodes. The two varieties G.T. 54-9 and G.2004-27 were the highest sensitive for rat damage, the variation in the percentage of rat damage between sugar cane varieties may be attributed to plant phenology, sugar content and other morphological and physiological characters of the variety. According to the present findings, the sugar cane variety G.2003-47 should be grown in areas which suffer from rodent problems.

Regardless of sugar cane variety and the site infestation, the main plants showed the lowest percentage of rat injury. However, the first ratoon proved to be more preferable to rats. The rat damage was much apparent in the first ratoon. The extensive agricultural practices and the phenology of plants in main plants may explain the low percentage of rat damage compared with that in and first ratoon.Rat damage was noticed either at the top or the base of the stalks but in some sugarcane varieties the damage was recorded at top and base of the stalks. Regardless of sugar cane variety, there was no marked difference between top and base infestation in ratoons. The top damage is caused by R.r.frugivorus. Rats usually build their nests in areas where the plants are dense and lodged. However, the bas damage was noticed to be caused by A.niloticus (Abdel-Gawadet al., 1982).

Table1. Percentage of rodent infestation in three sugar cane varieties planted at Sohag Governorate during two successive years $(2018-2019)$.

\begin{tabular}{|c|c|c|c|c|c|c|c|c|c|c|c|}
\hline \multirow{3}{*}{ Season } & \multirow{3}{*}{ Variety } & \multicolumn{10}{|c|}{ Damage in 4 replications } \\
\hline & & \multicolumn{2}{|c|}{$\mathrm{R} 1$} & \multicolumn{2}{|c|}{ R2 } & \multicolumn{2}{|c|}{ R3 } & \multicolumn{2}{|c|}{$\mathrm{R} 4$} & \multicolumn{2}{|c|}{ Mean } \\
\hline & & $\begin{array}{c}\text { D.S } \\
\%\end{array}$ & $\begin{array}{c}\text { D.I } \\
\%\end{array}$ & $\begin{array}{c}\text { D.S } \\
\%\end{array}$ & $\begin{array}{l}\text { D.I } \\
\%\end{array}$ & $\begin{array}{c}\text { D.S } \\
\%\end{array}$ & $\begin{array}{c}\text { D.I } \\
\%\end{array}$ & $\begin{array}{c}\text { D.S } \\
\%\end{array}$ & $\begin{array}{c}\text { D.I } \\
\%\end{array}$ & $\begin{array}{c}\text { D.S } \\
\%\end{array}$ & $\begin{array}{l}\text { D.I } \\
\%\end{array}$ \\
\hline \multirow{3}{*}{2018 main plant } & G.T. 54.9 & 16.00 & 7.29 & 20.00 & 8.16 & 10.00 & 10.00 & 10.00 & 9.09 & 14.00 & 8.64 \\
\hline & G..2004-27 & 10.00 & 7.14 & 16.00 & 7.29 & 6.96 & 11.90 & 13.33 & 8.75 & 11.50 & 8.77 \\
\hline & G.2003-47 & 16.00 & 7.69 & 10.00 & 4.62 & 20.00 & 6.35 & 16.00 & 4.35 & 15.50 & 5.63 \\
\hline \multirow{3}{*}{2019 first ratoon } & G.T. 54.9 & 10.00 & 10.34 & 13.00 & 5.00 & 13.00 & 8.64 & 23.00 & 7.80 & 14.75 & 7.95 \\
\hline & G..2004-27 & 23.30 & 7.86 & 20.00 & 6.78 & 6.67 & 13.16 & 16.00 & 7.84 & 16.49 & 8.91 \\
\hline & G.2003-47 & 10.00 & 7.58 & 13.00 & 7.50 & 13.00 & 7.14 & 16.00 & 5.00 & 13.00 & 6.81 \\
\hline
\end{tabular}

D.s \%: Damage of stalks\%

D.I\%: Damage of internodes\%

Data in table (2) show the weight of rodent infested and sound stalk of sugar cane In all samples, For three varieties the weight of sound stalks was much higher than that of the infested stalks. Thus, the rodent infestation may cause consider able reduction in sugar Cane yield.

Table2. Average weight in $\mathrm{kg}$ of the uninfested and infested stalks of three sugar cane varieties during two successive years (2018-2019).

\begin{tabular}{|c|c|c|c|c|}
\hline Year & Variety & Uninfested & Infested & Reduction\% \\
\hline \multirow{3}{*}{2018 main plant } & G.T. 54.9 & 54.600 & 34.300 & 37.180 \\
\cline { 2 - 5 } & G..2004-27 & 65.200 & 44.100 & 32.360 \\
\cline { 2 - 5 } & G.2003-47 & 52.700 & 36.100 & 31.500 \\
\hline
\end{tabular}


Damage Caused by Rodents to Sugar Cane Varieties and Juice Quality in Sohag Governorate

\begin{tabular}{|c|c|c|c|c|}
\hline \multirow{3}{*}{ 2019first ratoon } & G.T. 54.9 & 48.500 & 33.200 & 31.540 \\
\hline & G..2004-27 & 60.300 & 41.100 & 31.840 \\
\hline & G.2003-47 & 45.800 & 35.100 & 23.360 \\
\hline
\end{tabular}

Data in table (3-4) show chemical analysis for juice obtained from uninfested and infested stalks of sugar cane. Brix means the total soluble solids in the juice. For all varieties of sugar cane, infested stalks showed low brix values than uninfested stalks, The sucrose/cm or gm juice was also found to be influenced by rodent infestation. Values of sucrose were less infested stalks than that in the uninfested stalk for all varieties of sugar cane.

Since the infestation by rodent decreased the sucrose content and the purity of juice also decreased. Similar results on the effect of rodents infestation on juice purity was obtained by Ibrahim (1972). He revealed that the purity of sound cane was $85.5 \%$ and for the injured $77.6 \%$ Abazaid (1990) in his study on rodent damage to sugar cane in Upper Egypt found 20 to $40 \%$ reduction in yield and 30\% in final sucrose in the infested stalks of sugar cane. Bakri- Eman (2004) in her study on rodents damage to six sugar cane varieties proved that rodent damage reduced the juice quality of all varieties of Segar Cane in Sohag Governorate. Generally, rodent infestation caused reduction in sugar cane yield and sucrose content. The damage caused by rodents was comparatively higher in ratoons than in the main plants because the plants in the ratoons are more dense and soft than the main plant stalks. A greater loss in sugar yield may occur if damaged stems are break over. In Astralia, Hitchcock and KerKwyk (1975) showed little loss of sugar if stalks were bitten but not broken, but losses were significantly if canes broke over.

Table3. Some chemical properties of juice from uninfested and infested stalk of three sugar cane varieties in $1^{\text {st }}$ year(2017-2018)

\begin{tabular}{|c|c|c|c|c|c|c|c|c|}
\hline \multirow{2}{*}{ Variety } & \multicolumn{7}{|c|}{ Juice quality (chemical analysis) } \\
\cline { 3 - 9 } & & $\begin{array}{c}\text { Brix } \\
\text { weight }\end{array}$ & $\begin{array}{c}\text { Brix } \\
\text { volume }\end{array}$ & $\begin{array}{c}\text { Sucrose\% } \\
\text { cm.in juice }\end{array}$ & $\begin{array}{c}\text { Sucrose\%gm } \\
\text { in juice }\end{array}$ & $\begin{array}{c}\text { Purity } \\
\%\end{array}$ & Richness\% & $\begin{array}{c}\text { Sugar } \\
\text { recover\% }\end{array}$ \\
\hline \multirow{2}{*}{ G.T. 54-9 } & Uninfested & 19.31 & 20.86 & 17.30 & 16.01 & 82.79 & 12.97 & 10.75 \\
\cline { 2 - 9 } & Infested & 16.55 & 17.68 & 14.25 & 13.35 & 80.64 & 10.60 & 8.62 \\
\hline \multirow{2}{*}{ G. 2004-27 } & Uninfested & 19.50 & 21.08 & 18.00 & 16.64 & 85.38 & 13.47 & 11.50 \\
\cline { 2 - 9 } & Infested & 19.40 & 20.97 & 17.25 & 15.96 & 82.23 & 12.77 & 10.51 \\
\hline G. 2003-47 & Uninfested & 21.20 & 23.90 & 21.00 & 19.23 & 87.87 & 15.39 & 13.53 \\
\cline { 2 - 9 } & Infested & 19.00 & 20.98 & 17.15 & 16.18 & 83.41 & 12.95 & 10.80 \\
\hline
\end{tabular}

Table4. Some chemical properties of juice from uninfested and infested stalk of three sugar cane varieties in 2nd year (2018-2019)

\begin{tabular}{|c|c|c|c|c|c|c|c|c|}
\hline \multirow{2}{*}{ Variety } & & \multicolumn{7}{|c|}{ Juice quality (chemical analysis) } \\
\hline & & $\begin{array}{c}\text { Brix } \\
\text { weight }\end{array}$ & $\begin{array}{c}\text { Brix } \\
\text { volume }\end{array}$ & $\begin{array}{c}\text { Sucrose\%cm } \\
\text { in juice }\end{array}$ & $\begin{array}{l}\text { Sucrose } \% \text { gm. } \\
\text { in juice }\end{array}$ & $\begin{array}{c}\text { Purity } \\
\%\end{array}$ & Richness\% & $\begin{array}{c}\text { Sugar } \\
\text { recover\% }\end{array}$ \\
\hline \multirow{2}{*}{$\begin{array}{l}\text { G.T. } \\
54-9\end{array}$} & Uninfested & 19.44 & 21.02 & 17.04 & 16.09 & 82.76 & 13.19 & 10.93 \\
\hline & Infested & 17.20 & 18.26 & 14.53 & 13.57 & 79.60 & 10.86 & 8.65 \\
\hline \multirow{2}{*}{$\begin{array}{c}\text { G. } \\
\text { 2004-27 }\end{array}$} & Uninfested & 19.55 & 21.13 & 18.57 & 17.16 & 87.79 & 13.90 & 12.20 \\
\hline & Infested & 18.20 & 19.57 & 16.45 & 15.30 & 84.06 & 12.39 & 10.42 \\
\hline \multirow{2}{*}{$\begin{array}{c}\text { G. } \\
\text { 2003-47 }\end{array}$} & Uninfested & 21.90 & 23.90 & 21.00 & 19.24 & 87.87 & 15.39 & 13.52 \\
\hline & Infested & 19.00 & 20.50 & 17.00 & 15.76 & 82.93 & 12.61 & 10.45 \\
\hline
\end{tabular}

\section{REFERENCES}

[1] Abazaid, A.A. (1990). Efficiency of some common used rodenticides and some new alternatives against rodent in Qena Governorate. M.Sc. Thesis, Fac. Agric., Assiut Univ., pp.

[2] Abdel-Gawad, K.H., Salit, A.M. and Maher Ali, A. (1982) Damage caused by rodents in sugar-cane plantation. Assiut J. Agric. Sci. 13 (2): 63-71

[3] Ali, M.K. (1991) Recent trends in rodent control and efficacy of its chemical agents. Ph.D. Thesis, Fac Agric., Assiut Univ., pp. 154.

[4] Ali, M.K. and Farghal, A.I. (1994). Damage caused by rodent in sugar beet plantation. Assiut J. Agric. Sci. 25 (3): 209-213.

[5] Bakri- Eman, A. A.(2004): Ecological and toxicological studies on some rodent speciesinfesting sugar cane crop. M. Sc. Thesis Face. Science. AL Azhar Univ. PP 178. 
[6] Dykstra, W.W. (1966). The economic importance of commensal rodents. WHO/Vector control. 66: 217.

[7] Economist (1981). World commodity (1982) Food, feedstuffs and . beverages Economist Intelligence Unit., London, 98 pp.,

[8] EL. Rawy, A. A. A (2017) Ecological studies on Some rodents caused damage on sugar crops at Assuit and QenaGovernorates and its control M. Sc. Thesis Face. Science. AL Azhar Univ. PP 112.

[9] F.A.O. (1979) FAO production year Food 33 volume book an agriculture organization of the Unite

[10] Hitchcock, B.E. and Kerkwyk, R.E. (1975). Further aerial baiting trials against rats in cane fields. pp. 5964. In Proceedings of the 40th Conference of the Queensland Society of Sugar cane Technologists.

[11] Ibrahim, M.M. (1972) Damage and control of Nile grass rat, A. niloticus. $1^{\text {st }}$ Sci. Symp. on Rodent and their control in Egypt.

[12] Meade, G.F. and Chen, G.C.T. (1977). Cane sugar hand book 10th. Ed. A Wiley Inter. Sco. Publ., John Wiley \& Sons, New York, London, Sydney.

[13] Samson P.,Sallam, N. and Chandler,K.(2013):Rat management in sugar cane . Australia S RA.

Citation: Desoky A.S.S., et.al," Damage Caused by Rodents to Sugar Cane Varieties and Juice Quality in Sohag Governorate” International Journal of Research Studies in Zoology, vol. 5, no. 4, p. 22-25, 2019. DOI. http://dx.doi.org/10.20431/2454-941X.050404.

Copyright: (C) 2019 Authors. This is an open-access article distributed under the terms of the Creative Commons Attribution License, which permits unrestricted use, distribution, and reproduction in any medium, provided the original author and source are credited. 